\title{
Working conditions and depression in hospital emergency service nurses
}

\author{
Condições de trabalho e depressão em enfermeiros de serviço hospitalar de emergência \\ Condiciones de trabajo y depresión en enfermeras de servicio de urgencias hospitalarias
}

'Universidade Federal de São Paulo. São Paulo, São Paulo, Brazil.

How to cite this article:

Silva MRG, Marcolan JF. Working conditions and depression in hospital emergency service nurses.

Rev Bras Enferm. 2020;73(Suppl 1):e20180952. doi: http://dx.doi.org/10.1590/0034-7167-2018-0952

Corresponding author:

Marcia Regina Guedes Silva

E-mail: gasperangel@gmail.com

EDITOR IN CHIEF: Antonio José de Almeida Filho ASSOCIATE EDITOR: Maria Saraiva

Submission: 12-11-2018

Approval: 04-23-2020

\begin{abstract}
Objective: to analyze the presence, intensity and factors related to working conditions for depressive symptoms in hospital emergency nurses in the east of São Paulo. Methods: a descriptive, exploratory, quantitative and qualitative study, which applied psychometric scales and interview script. Results: nurses (95.24\%) had depressive symptoms by the assessment scales by the observer, most with mild and moderate intensity. Inadequate working conditions led to suffering. Factors that trigger depressive symptoms were: disorganized work; harmful relationship with immediate management; inappropriate physician behavior; aggressions; lack of inputs, infrastructure and human resources; professional devaluation. Identified professionals with depressive symptoms who, because they were unaware of being affected by the disorder, did not seek treatment, continued to perform activities that compromised their physical and mental health, promoting damage to the assistance provided. Final considerations: high frequency of depressive symptoms. The precarious work environment negatively influenced the care and development of depressive symptoms.
\end{abstract}

Descriptors: Depression; Working Conditions; Occupational Health; Emergency Nursing Hospital Emergency Services.

\section{RESUMO}

Objetivo: analisar presença, intensidade e fatores relacionados às condições de trabalho para sintomatologia depressiva em enfermeiros de emergência intra-hospitalar da zona leste paulistana. Métodos: estudo descritivo exploratório, abordagem quantitativa e qualitativa por aplicação de escalas psicométricas e roteiro de entrevista. Resultados: 95,24\% dos enfermeiros apresentaram sintomatologia depressiva pelas escalas de avaliação pelo observador, maioria com intensidade leve e moderada. Condições inadequadas de trabalho levaram ao sofrimento. Fatores desencadeantes da sintomatologia depressiva foram desorganização do trabalho; relacionamento prejudicial com chefia imediata; comportamento inadequado do médico; agressões; falta de insumos, infraestrutura e recursos humanos; desvalorização profissional. Identificados profissionais com sintomatologia depressiva que, por desconhecerem estar acometidos pelo transtorno, não procuraram por tratamento, continuaram a desempenhar atividades a comprometer sua saúde física e mental, promover prejuízo a assistência prestada. Considerações finais: alta frequência de sintomatologia depressiva. $\mathrm{O}$ ambiente de trabalho precarizado influenciou negativamente na assistência e desenvolvimento da sintomatologia depressiva. Descritores: Depressão; Condições de Trabalho; Saúde do Trabalhador; Enfermagem em Emergência; Serviço Hospitalar de Emergência.

\section{RESUMEN}

Objetivo: analizar la presencia, intensidad y factores relacionados con las condiciones de trabajo para los síntomas depresivos en enfermeras de urgencias hospitalarias en el lado este de São Paulo. Métodos: estudio exploratorio descriptivo, enfoque cuantitativo y cualitativo mediante la aplicación de escalas psicométricas y guión de entrevista. Resultados: el 95,24\% de las enfermeras tenían síntomas depresivos según las escalas de evaluación del observador, la mayoría con intensidad leve y moderada. Las condiciones de trabajo inadecuadas provocaron sufrimiento. Los factores desencadenantes de los síntomas depresivos fueron el trabajo desorganizado; relación perjudicial con la gestión inmediata; comportamiento inapropiado del médico; agresiones falta de insumos, infraestructura y recursos humanos; devaluación profesional. Profesionales identificados con síntomas depresivos que, debido a que no sabían ser afectados por el trastorno, no buscaron tratamiento, continuaron realizando actividades que comprometían su salud física y mental, promoviendo daños a la asistencia brindada. Consideraciones finales: alta frecuencia de síntomas depresivos. El ambiente de trabajo precario influyó negativamente en el cuidado y el desarrollo de los síntomas depresivos. Descriptores: Depresión; Condiciones de Trabajo; Salud Laboral; Enfermería de Urgencia; Servicio de Urgencias Hospitalarias. 


\section{INTRODUCTION}

Depressive disorder is a public health problem because it generates disability due to symptoms, with damage to personal and professional life ${ }^{(1)}$.

The Global Burden of Disease survey, carried out in 188 countries, from 1990 to 2013 , showed an increase of $53.43 \%$ in the prevalence of depressive disorder in the population, becoming the second leading cause of illness worldwide ${ }^{(2)}$.

Work is a cause of mental suffering, precarious work-worker relationship takes the form of demands that are humanly impossible to be performed as a way of managing people. Individuals are constantly under pressure and tension due to possible dismissal, making them strive to fulfill such demands, coupled with ethical issues as an important factor in triggering psychological suffering, because individuals inserted in the labor market need to make decisions that confront ethical sense on a daily basis. Evil starts to be seen as something necessary and even characteristic of today, which inevitably results in physical and mental suffering ${ }^{(3)}$.

Nursing work is considered a painful activity, as it acts directly with human suffering. It causes illness due to wear and stress experienced in the performance of daily professional activities. This triggers a state of illness referred to as diffuse pain and sadness, leading to the removal of the professional, in addition to the precariousness of personal life through flexible hours. Therefore, it makes the employee an object available to the company at any time ${ }^{(4)}$. Precarious work in nursing has been fundamental for the illness of professionals and damage to the assistance provided.

The study has its importance, as it evidenced in the working conditions of nurses belonging to the hospital emergency service in the east of São Paulo the existence of factors that trigger depressive symptoms, since there was no data on this topic in this region.

\section{OBJECTIVE}

To analyse the presence, intensity and factors related to working conditions for depressive symptoms in hospital emergency nurses in the east of São Paulo.

\section{METHOD}

\section{Ethical aspects}

Respect for the rules that regulate research with human beings was guaranteed. The research took place after the consent of the City hall of São Paulo, with the approval of its Research Ethics Committee and the Universidade Federal de São Paulo. The professional, upon having agreed to participate, was asked to sign a commitment by signing the Informed Consent Term.

\section{Theoretical-methodological framework}

Analysis was performed by the theoretical framework of occupational mental health and methodological framework by thematic content analysis ${ }^{(5)}$.

\section{Type of study}

This descriptive exploratory, quantitative and qualitative study was carried out in hospital emergency units of Hospital Municipal Alípio Correa Netto (Ermelino Matarazzo) and Hospital MunicipalDr. Waldomiro de Paula (Itaquera). Data collection period was between February and October 2017. The Equator platform guidelines were adopted, in accordance with COREQ and STARD 2015.

\section{Methodological procedures}

A mapping of nurses in hospital emergency units was carried out, distributed by hospitals participating in the research, to include all work shifts (day and night). During the first contact with the professional, it was explained what the research comprised, doubts were resolved, and after consenting to participate, an interview was conducted on the date, place and time agreed.

\section{Hypothesis}

The hypothesis raised by the researchers is that nurses in the hospital emergency department had depressive symptoms due to the occupational factor; psychological distress related to the dynamics and working conditions, interfering in the quality of care by discussing the issues about illness in the nurses' work environment.

\section{Data source}

The population was composed of nurses from the hospital emergency sector. The stratified non-probabilistic and random sample was defined by the convenience of $30 \%$ of the professionals evenly distributed between the work shifts (day and night).

It was used as an inclusion criterion to have at least two years of experience as a nurse in the hospital emergency area and to work for at least six months in the hospital emergency area at the institution where the study was carried out. Twenty-one nurses participated in the research.

\section{Data collection and organisation}

The instruments used for data collection were psychometric scales for depressive symptoms, applied in the Beck Depression Inventory, the Hamilton Depression Rating Scale, and the Montgomery-Asberg Depression Rating Scale. For these scales, the participant was asked to answer for each item which alternative best described their feelings in the last week, including the day of the survey.

Then, a semi-structured interview script was prepared by the researchers through an interview recorded on an audio device and transcribed in full. The interview script included open questions whose objective was to assess the conditions expressed by the professionals with sociodemographic information, history of depressive symptoms and factors related to depressive disorder. As for the factors related to depressive symptoms, there were guiding questions to describe how they felt about the activities developed as a result of their profession, the triggering factors of depressive symptoms, their perception about the depressive 
disorder reported or pointed out by the scales and how it influenced performance of care.

\section{Data analysis}

Qualitative analysis of the data was performed using the thematic content analysis methodological framework $^{(5)}$. The qualitative analysis of the questions in the interview script showed the category "inadequate working conditions lead to suffering" and its thematic units: disorganisation of work; harmful relationship with managers; inappropriate physician behavior; attacks by patients, family members and medical residents; lack of inputs, infrastructure and human resources; and professional devaluation. To configure the quantitative analysis in relation to the psychometric scales, analyses were performed according to the specific scores for each one and statistical treatment of the results of each scale with the sociodemographic variables by means of tests. To compare proportions between groups, Pearson's chi-square test or Fisher's exact test were applied, when indicated. The evaluation of quantitative variables between the groups was performed by Student's t-test for independent measures or the Mann-Whitney test, when applicable. Linear correlations were drawn between the three depression assessment instruments according to Pearson's method. Results with a type I error probability of less than $5.00 \%(P<0.05)^{(6)}$ were considered statistically significant.

Data were tabulated with the aid of the Microsoft Office 2010 package and analysed with with SPSS (Statistical Package Social Science), version 20.0

\section{RESULTS}

Twenty-one nurses participated in the research, 13 nurses worked at the hospital emergency unit of Hospital Municipal Prof. Alípio Correa Netto (Ermelino Matarazzo) and 08 nurses at the Hospital Municipal Dr. Waldomiro de Paula (Itaquera).

Analysis of the sociodemographic profile showed a majority composed of the female sex (57.14\%), age between 28 and 36 years (47.62\%), married (61.91\%), without children (47.60\%), evangelical (28.58\%) and individual monthly income between $\$ 6,000$ and $\$ 10,000$ (57.14\%). Concerning workdays, $52.38 \%$ declared to work 30 to 36 hours a week and $47.62 \%$ of nurses declared to work 40 to 72 hours a week. Most (57.14\%) had no other employment, and working time at the institution was between two and eight years (76.19\%). Fifty-two point thirty-eight percent had training time for more than nine years and $76.19 \%$ reported having worked for one to eight years in the emergency area.

As for having a previous or current diagnosis of depressive disorder, 18 (85.71\%) answered that they did not and 3 (14.29\%) that they did; as for treatment, they reported the use of anxiolytics and antidepressants.

There are 12 (57.14\%) who did not consider themselves with depressive disorder at the time of the interview and 9 (42.86\%) who did. Table 1 shows the data related to the results of the psychometric scales.
Directly proportional and statistically significant correlations were observed between the three scales studied. The correlation between the score observed on the Montgomery-Asberg scale and the score on the Hamilton scale showed the best coefficient $(r=0.811)$, with a strong correlation. The correlation between the Beck and Hamilton scales and between the Beck and Montgomery-Asberg scales are significant with moderate intensity.

It was not possible to observe demographic or occupational characteristics significantly associated with the finding using the Beck scale. For the Hamilton and Montgomery-Asberg scales, the number of children and the self-report of depression were significantly associated with moderate or severe depression, as we can see in Tables 2 and 3.

Qualitative analysis of the questions in the interview script resulted in the category "inadequate working conditions lead to suffering" and its thematic units: disorganisation of work; harmful relationship with managers; inappropriate physician behavior; attacks by patients, family members and medical residents; lack of inputs, infrastructure and human resources; and professional devaluation.

In the thematic unit "disorganisation of work", complaints appeared regarding the lack of protocols, rules and routines that would standardise assistance. Facilitating the service of professional nurses, its inexistence opens the possibility of interpretation by each nurse, hindering the continuity and quality of care:

I feel frustrated, upset, because... what we can do for the patient with the conditions that the institution gives us is very little, whether due to the workload, it seems that something is suspended. There is no continuity in the service, there is no protocol, it seems that each one does the thing he/she wants in a different way, which leaves something to be desired in the quality of the assistance provided. Nothing is done well and with zeal, there is a lack of quality, it seems that we work for production, and as much as we do our best, there is no way to overcome this demand, it is impossible. (I1) 
Table 2 - Sample characteristics according to the finding of depression from the Hamilton inventory. São Paulo, Brazil, 2018

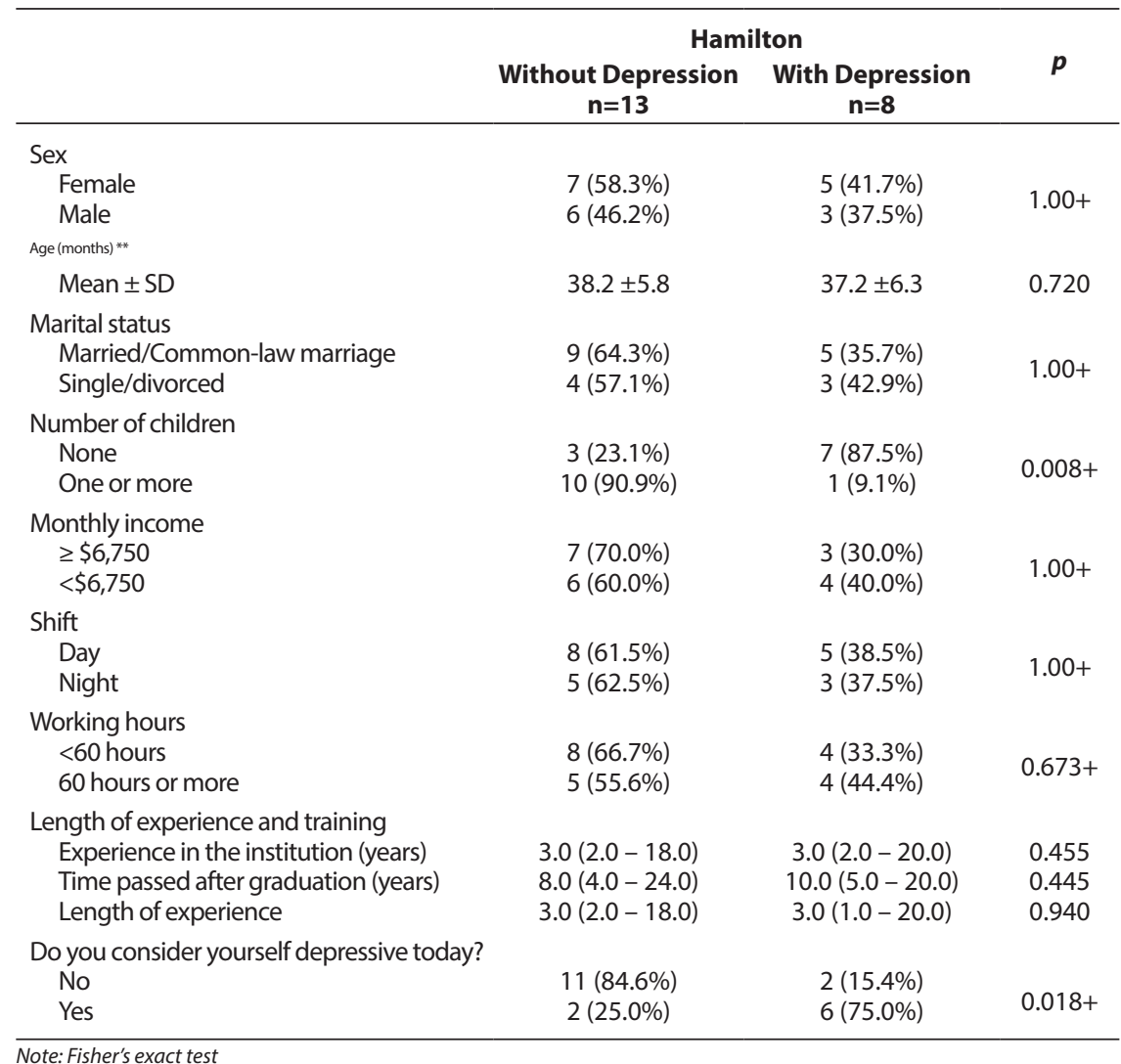

Table 3 - Sample characteristics according to the finding of depression from the MADRS scale. São Paulo, Brazil, 2018

\begin{tabular}{|c|c|c|c|}
\hline & $\begin{array}{r}\text { MADRS } \\
\begin{array}{r}\text { Without Depression/Light } \\
n=13\end{array} \\
\end{array}$ & $\begin{array}{c}\begin{array}{c}\text { With Depression } \\
\mathbf{n}=\mathbf{8}\end{array} \\
\end{array}$ & $p$ \\
\hline $\begin{array}{l}\text { Sex } \\
\quad \text { Female } \\
\text { Male }\end{array}$ & $\begin{array}{l}7(58.3 \%) \\
5(55.6 \%)\end{array}$ & $\begin{array}{l}5(41.7 \%) \\
4(44.4 \%)\end{array}$ & 0.899 \\
\hline $\begin{array}{l}\text { Age (years) } \\
\text { Mean } \pm S D\end{array}$ & $38.7 \pm 5.7$ & $36.6 \pm 6.1$ & 0.435 \\
\hline $\begin{array}{l}\text { Marital status } \\
\text { Married/Common-law marriage } \\
\text { Single/divorced }\end{array}$ & $\begin{array}{l}9(64.3 \%) \\
3(42.9 \%)\end{array}$ & $\begin{array}{l}5(35.7 \%) \\
4(57.1 \%)\end{array}$ & $0.397+$ \\
\hline $\begin{array}{l}\text { Number of children } \\
\text { None } \\
\text { One or more }\end{array}$ & $\begin{array}{c}2(20.0 \%) \\
10(90.9 \%)\end{array}$ & $\begin{array}{c}8(80.0 \%) \\
1(9.1 \%)\end{array}$ & $0.002+$ \\
\hline $\begin{array}{l}\text { Monthly income } \\
\quad \geq \$ 6,750 \\
<\$ 6,750\end{array}$ & $\begin{array}{l}6(60.0 \%) \\
6(60.0 \%)\end{array}$ & $\begin{array}{l}4(40.0 \%) \\
4(40.0 \%)\end{array}$ & $1.00+$ \\
\hline $\begin{array}{l}\text { Shift } \\
\text { Day } \\
\text { Night }\end{array}$ & $\begin{array}{l}8(61.5 \%) \\
4(50.0 \%)\end{array}$ & $\begin{array}{l}5(38.5 \%) \\
4(50.0 \%)\end{array}$ & $0.673+$ \\
\hline $\begin{array}{l}\text { Working hours } \\
<60 \text { hours } \\
60 \text { hours or more }\end{array}$ & $\begin{array}{l}8(66.7 \%) \\
4(44.4 \%)\end{array}$ & $\begin{array}{l}4(33.3 \%) \\
5(55.6 \%)\end{array}$ & 0.309 \\
\hline $\begin{array}{l}\text { Length of experience and training } \\
\text { Experience in the institution (years) } \\
\text { Time passed after graduation (years) } \\
\text { Length of experience (years) }\end{array}$ & $\begin{array}{l}3.0(2.0-18.0) \\
7.0(4.0-24.0) \\
2.5(2.0-18.0)\end{array}$ & $\begin{array}{c}3.0(2.0-20.0) \\
11.0(5.0-20.0) \\
3.0(1.0-20.0)\end{array}$ & $\begin{array}{l}0.227 \\
0.335 \\
0.608\end{array}$ \\
\hline $\begin{array}{l}\text { Do you consider yourself depressive toda) } \\
\text { No } \\
\text { Yes }\end{array}$ & $\begin{array}{c}11(84.6 \%) \\
1(12.5 \%)\end{array}$ & $\begin{array}{l}2(15.4 \%) \\
7(87.5 \%)\end{array}$ & $0.002+$ \\
\hline
\end{tabular}

Inadequate relationship with the immediate superior was considered harmful. There were complaints regarding the lack of support from the boss, disregard for the reality experienced by nurses in the institutions surveyed and favoring certain employees due to personal proximity to the boss.

The main problem, for me, is the type of leadership developed by my boss... she is the main problem... I have no encouragement from the boss, who only oppresses and depresses her employees... she is inadequate, a type of boss that causes discord in the sector. She omits... when she takes a position, it is always against the nurse... my hope is to ask for a transfer... she uses us, makes us do things that are not our job. In addition, we are already used to having a boss who overlooks bad behavior from people who do wrong things and ends the morale of those who do things correctly, discrediting us and making us feel bad, feeling indecisive and gradually losing our confidence in ourselves.(I13)

Inappropriate physician behavior was also identified as a factor of suffering.

What bothers me deeply is the disorganisation here in the emergency room, the neglect of physicians... who only fill the emergency room, they don't even look at patients properly, and that bothers me... there should be greater awareness between the two teams because one cannot live without the other, if somebody's work is not done I cannot do mine and vice versa. (I2)

Disrespect can also be observed in the form of aggression suffered by nurses in the performance of their duties by not only the medical team, but also by patients and companions, contributing to the feeling of fear, disrespect and devaluation to demotivate nurses:

... I have suffered verbal aggression here... I am afraid to work at certain times... it is horrible here, the population does not understand the reality of health services and they get irritated, it is the moment when they attack you... I felt horrible 
when I was assaulted and it was only verbally... I was scared, you know, scared even to work in the following days. Nothing had been done to help me out, neither in the past nor after, like going to a psychologist....(18)

Another important point mentioned was the devaluation and lack of social recognition referred to as an obstacle to satisfaction of professional nurses:

The population does not even know what the nurse does... for them, all those who are not physicians are nurses... this is a profound disrespect, a lack of appreciation... that's why I say the nurse is very active and is totally disrespected; disrespected by the team and by the population. (I3)

Physical structure was perceived as inadequate by nurses when, in partnership with their team, had to make greater efforts to guarantee the provision of assistance to critically ill patients and encountered obstacles resulting from precarious work such as inadequacy in the number of employees, combined with terrible structural conditions of services to which professionals were inserted:

There are no beds ... which increases the number of emergency room visits... the reality of work l am in is not the best, the building is old and undergoing renovations continuously ... we change places more often, this part of the ER that I am working on today is the most modern and recently opened, so here is less needed than in other sectors of the ER. (I7)

Nursing staff is compromised, which ends up discouraging us... the lack of human resources in this institution forces you to do things that are not your job ... my service is left aside, what is mine ceases to be done (14).

The absence of material is perceived in the emergency unit, translated in the statements:

... here, medicine is missing, material is missing, everything is missing, after all you know that public service has nothing. Structure is precarious, there is no stretcher, SAMU stretchers remain in the ER until there is a stretcher to place the patient, which is hard. (I15)

It was possible to identify professionals with depressive symptoms who, because they were unaware of being affected by the disorder, did not seek treatment, continued to perform their activities, compromising their physical and mental health, with resonance in the quality of care.

After identifying depressive symptoms in nurses, guidance and referral for psychiatric or psychological evaluation or both were carried out, respecting the ethical principles of the research.

\section{DISCUSSION}

Absence of norms, flows, and routines or inadequacy of them is a factor for the development of mental disorders due to lack of standardisation of conduct. Thus, the nursing team is weakened in the development of their functions as a lack of clarity in the functions and tasks to be performed by nurses, which reduces their autonomy ${ }^{(7)}$.
The ineffective relationship with the boss is harmful, resulting in demotivation, contributing to the nurse's conduct to a process of discontent, difficulty in communication, as she believes that her participation in the care process is considered insignificant. This generates frustration, dissatisfaction and the culmination of a disharmonious relationship ${ }^{(8)}$, reinforcing the data found in our study.

Supporting our data, studies point to disrespect from the medical team, which ignores the efforts of nurses to perform their functions in the best possible way in view of the precarious conditions of care. They even circumvent the feeling of neglect felt by patients due to lack of commitment with which they are treated and the inadequacy of treatment due to the lack of inputs. Nurses end up feeling devalued, decreasing the efficiency and quality of the care provided and promoting a constant struggle for the survival of patients amid the chaos established around them ${ }^{(9-10)}$.

Even with all these efforts, among users of public health services in Brazil, 64\% recognized the existence of nurses in the nursing category. However, they did not identify their attributions or importance in the care process performed with patients ${ }^{(11)}$, which comes with the data from our study.

In addition to the factors mentioned above, there is an inadequate infrastructure, affecting not only the quality of care, but the professional. Workers recognize that they are working in an inadequate number, the need to change the structural conditions of the services and they know that the worker's overload is often related to the need to deploy to sort the assistance out to be performed in favor of maintaining life of patients ${ }^{(12)}$.

A study carried out with nurses identified this same difficulty pointed out in our study in relation to the inadequate physical structure for care. Physical spaces stood out where patients are placed on an uncomfortable stretcher with risk of falling and irregular dependencies for personal hygiene activities and for an inadequate number of employees, which can compromise assistance ${ }^{(13)}$

Inadequacy in the number of professionals was also observed in a study carried out in a critical sector with 81 nursing assistants and showed that undersized picture affects the quality and safety of care, in addition to compromising the professional identity of nurses ${ }^{(14)}$.

A study in 65 hospitals in South Korea concluded that nursing staff adequacy is essential for the quality and safety of care, contributing to reduce the negligence provided by the team due to the quantity to be attended to ${ }^{(15)}$.

It is noted the absence of material perceived as a stress factor among the members of the nursing team, who, in their desire to meet the needs of patients, come into conflict over the dispute over the material resulting in psychological suffering and with this emotional exhaustion ${ }^{(16)}$.

Another study showed that the lack of inputs and materials reveals the difficulties of interprofessional relationships that exist between the teams, transforming the work environment into a more conflicted and prone to tensions than usual, which makes it difficult to provide dignified and quality patient care ${ }^{(17)}$. It was also observed in critical units, where it was evident that the lack of inputs or their low quality triggered a cascade of events considered stressful to the multidisciplinary and nursing staff. This affected the assistance provided to patients and increased financial expenses to perform care ${ }^{(18)}$. 
Data obtained in the city of São Paulo reinforce the idea of work overload found in our study, as there was an excess of attributions to nurses who felt overloaded in relation to work, favoring psychic illness ${ }^{(19)}$. It was also evidenced by a study carried out with 161 assisting nurses in Taiwan, the correlation of physical and mental overload resulting from excessive work activities as a trigger of depressive disorder ${ }^{(20)}$.

There was a correlation between inadequate working conditions and predisposition to depressive disorders in a study where $91.3 \%$ of nurses reported that working conditions contributed to mental illness due to depressive disorder, the most pointed being the lack of human and material resources ${ }^{(21)}$.

Precarious work was evident in a study carried out with nursing workers in a university hospital in the State of Rio de Janeiro. This precariousness was highlighted by the scarcity of material, inadequate human resources, increased work rhythm and inadequate physical plant. There was a clear organisational intention to seek to reduce costs and increase productivity, but with little concern for the health of workers ${ }^{(22)}$.

A study carried out in the State of Bahia found that the insufficient number of employees to perform complex care, coupled with the lack of inputs, transforms the quality of care in a harmful way. This makes the nursing professional a task performer, who must perform their duties quickly so that everyone can be attended to, regardless of the quality of care ${ }^{(23)}$.

It should also be noted that, in our study, most nurses did not recognize themselves as ill. This fact hindered the search for help that would make it possible to reestablish it, as well as encouraging momentary relief strategies in the face of inadequate conditions in their work environment. These strategies were considered inadequate, of short duration and non-resolute ${ }^{(20)}$.

Such coping strategies were also seen in a study carried out with 402 nurses from a private hospital followed for a period of 12 months. This reinforces the idea of punctual relief of the depressive symptoms presented, without its effective resolution, which negatively influenced the assistance ${ }^{(24)}$. A study with nurses in the Family Health Strategy program showed that in addition to not seeing themselves as sick, they were afraid to seek help, as they felt ashamed of the situation they were living in, in addition to the fear of social discrimination suffered by people with disorders psychiatric ${ }^{(19)}$.

\section{Study limitations}

As limitations of the study, there was a reduced number of participants and use of only two hospitals due to institutional refusal to authorize the study in all eight units in the east side of São Paulo.

\section{Contributions to nursing, health, and public policies}

In addition to contributing to the knowledge of occupational mental health of nursing professionals, this study contributes with the managers of the units surveyed, as it leads to the recognition of the reality that exists in these institutions. This makes it possible to make improvements in the working conditions of professionals, with a reduction in the suffering of professionals and an improvement in assistance to health equipment users.

\section{FINAL CONSIDERATIONS}

Through the application of psychometric scales to assess depression, it was possible to show the high frequency of depressive symptoms, of mild and moderate intensity, in the sample of nurses studied. When analysing the triggering factors, it was concluded that working conditions were precarious. There was constant overload due to the lack of human and material resources, inadequate physical structure, professional devaluation and harmful interpersonal relationships, especially with the respective leadership and the medical team. This negatively influenced the provision of assistance, being the main source of causing psychological distress in professionals.

\section{REFERENCES}

1. World Federation for Mental Health (US). The ICD - 10 Classification of mental and behavioural disorders: clinical descriptions and diagnostic guidelines[Internet]. United States of America: World Federation for Mental Health. 2016 [cited 2019 Feb 10]. Available from: https://www.who. int/classifications/icd/en/bluebook.pdf

2. Vos T, Barber RM, Bell B, Villa AB, Biryukov S, Bolliger I, et al. Global, regional, and national incidence, prevalence, and years lived with disability for 301 acute and chronic diseases and injuries in 188 countries, 1990 - 2013: a systematic analysis for the global burden of disease study 2013. Lancet [Internet]. 2015 [cited 2018 Aug 22];386(9995):743-800. Available from: https://www.thelancet.com/journals/lancet/article/ PIIS0140-6736(15)60692-4/fulltext

3. Dejours C. A banalização da injustiça social. Rio de Janeiro: Fundação Getúlio Vargas; 2006. 160 p.

4. Machado LSF, Rodrigues EP, Oliveira LMM, Laudano RCS, Nascimento SCL. Agravos à saúde referidos pelos trabalhadores de enfermagem em um hospital público da Bahia. Rev Bras Enferm. 2014;67(5):684-91. doi: 10.1590/0034-7167.2014670503

5. Bardin L. Análise de conteúdo. Lisboa: Edições 70; 2011. 280 p.

6. Dawson B, Trapp RG. Bioestatística básica e clínica. 3. ed. Rio de Janeiro: Mc Graw Hill, 2003.

7. Lu DM, Sun N, Hong S, Fan YY, Kong FY, Li QJ. Occupational stress and coping strategies among emergency department nurses of China. Arch Psychiatr Nurs. 2015;29(4):208-12. doi: 10.1016/j.apnu.2014.11.006

8. Jerng JS, Huang SF, Liang HW, Chen LC, Lin CK, Huang HF, et al. Workplace interpersonal conflicts among the healthcare workers: retrospective exploration from the institutional incident reporting system of a university-affiliated medical center. PLoS ONE. 2017;12(2):e0171696. doi: 10.1371/journal.pone.0171696 
9. Enns V, Currie S, Wang J. Professional autonomy and work setting as contributing factors to depression and absenteeism in Canadian nurses. Nurs Outlook. 2015;63(3):269-277. doi: 10.1016/j.outlook.2014.12.014

10. Itzhaki M, Bluvstein I, Peles Bortz A, Kostistky H, Bar Noy D, Filshtinsky V et al. Mental health nurse's exposure to workplace violence leads to job stress, which leads to reduced professional quality of life. Front Psychiatry. 2018; 27;9. doi: 10.3389/fpsyt.2018.00059

11. Silva ATC, Lopes CS, Susser E, Menezes PR. Work-related depression in primary care teams in Brazil. Am J Public Health. 2016;106(11):1990-7. doi: 10.2105/AJPH.2016.303342

12. Alves S, Santos R, Oliveira R, Yamaguchi M. Mental health services: perception of nursing in relation to overload and working conditions. Rev Pesqui: Cuid Fundam [Internet]. 2018 [cited 2018 Oct 14];10(1):25-9. Available from: http://www.seer.unirio.br/index.php/ cuidadofundamental/article/view/5929

13. Nascimento ERP, Silva SG, Souza BC, Souza DD, Germer Netto A. Environment of a hospital emergency unit for the elderly care: perception of nursing professionals. Esc Anna Nery [Internet]. 2015 [cited 2018 Oct 22];19(2):338-42. doi: 10.5935/1414-8145.20150046

14. Inoue KC, Matsuda LM. Dimensionamento de pessoal de enfermagem em unidade de terapia intensiva para adultos. Acta Paul Enferm[Internet]. 2010[cited 2019 May 06];23(3):379-84. doi: 10.1590/S0103-21002010000300011

15. Cho E, Lee N, Kim E, Kim S, Lee K, Park K, et al. Nurse staffing level and overtime associated with patient safety, quality of care, and care left undone in hospitals: a cross-sectional study. Int J Nurs Stud. 2016;60:263-271. doi: 10.1016/j.ijnurstu.2016.05.009

16. Martins JT, Ribeiro RP, Bobroff MCC, Marziale MHP, Robazzi MLCC, Mendes AC. Meaning of workload on the view of cleaning professionals. Acta Paul Enferm. 2013;26(1):63-70. doi: 10.1590/S0103-21002013000100011

17. Pereira LA, Hirsch CD, Silveira RS, Barlem JGT, Schalenberger CD, Barlem ELD. Nurse-leader construction process barries: an ethnonursing. Rev Enferm UFPE[Internet]. 2018 [cited 2019 Jan 02];12(5):1381-9. Available from: https://periodicos.ufpe.br/revistas/revistaenfermagem/ article/view/230730

18. Duarte S, Queiroz A, Büscher A, Stipp M. Human error in daily intensive nursing care. Rev Latino-Am Enferm. 2015;23(6):1074-81. doi: 10.1590/0104-1169.0479.2651

19. Fernandes DM, Marcolan JF. Work and depression symptoms in family health strategy nurses. SMAD, Rev Eletrôn Saúde Mental Alcool Drog. 2017;13(1):37-44. doi: 10.11606/issn.1806-6976.v13i1p37-44

20. Chen CH, Wang J, Yang CS, Fan JY. Nurse practitioner job content and stress effects on anxiety and depressive symptoms, and self-perceived health status. J Nurs Manag. 2016;24(5):695-704. doi: 10.1111/jonm.12375

21. Oliveira FP, Mazzaia MC, Marcolan JF. Symptoms of depression and intervening factors among nurses of emergency hospital services. Acta Paul Enferm. 2015;28(3):209-15. doi: 10.1590/1982-0194201500036

22. Gonçalves FGA, Souza NVDO, Pires AS, Santos DM, D'Oliveira CAFB, Ribeiro LV. Neoliberal model and its effects on the health of the nursing worker. Rev Enferm UERJ [Internet]. 2014 [cited Jun 29];22(4):519-25. Available from: http://www.facenf.uerj.br/v22n4/v22n4a14.pdf

23. Ferreira SC, Santos MJOL, Estrela FM. Nursing activities score and the care in the intensive care unit. Arq Ciênc Saúde [Internet]. 2016 [cited 2018 Oct 14];23(1):63-7. Available from: http://www.cienciasdasaude.famerp.br/index.php/racs/article/view/400

24. Duan-Porter W, Hatch D, Pendergast JF, Freude G, Rose U, Burr H et al. 12-month trajectories of depressive symptoms among nurses: contribution of personality, job characteristics, coping, and burnout. J Affect Disord. 2018;234:67-73. doi: 10.1016/j.jad.2018.02.090 